\title{
BELEWENIS VAN MOEDERS VAN JONG HIPERAKTIEWE KINDERS
}

\section{AJ Cilliers, M Greeff en M Poggenpoel}

\begin{abstract}
SAMEVATTING

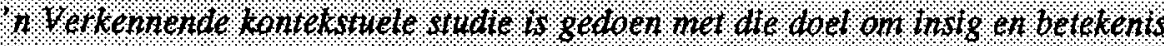

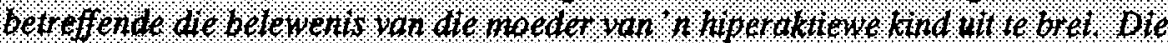

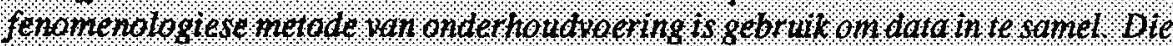
onder houde is op baht opgeneem en datrna verbath getranskrbeer. Die

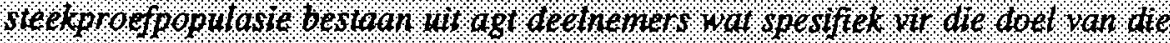

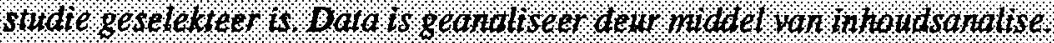

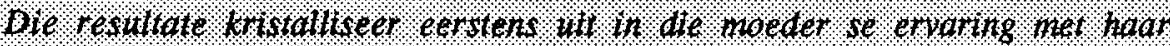

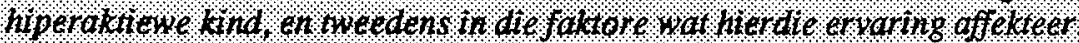

Bie envaring landie moeder word ver vat in had betrokkenheid by had kind, en in

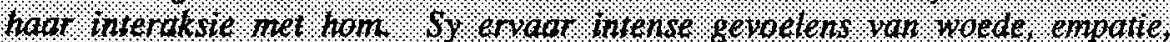

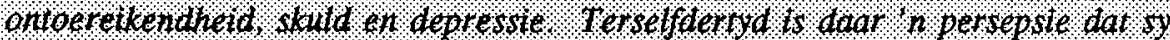

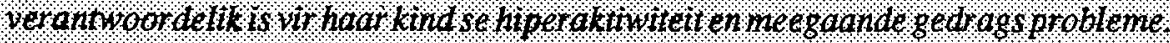

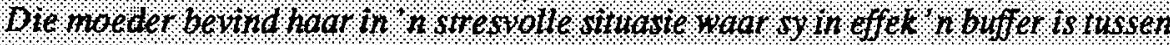

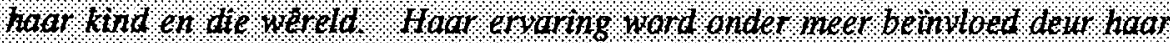
geloofstelsel. persoontike stres, die hiperaktewe lind se gedrog. en die

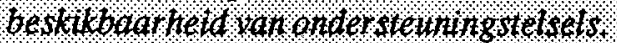

Op grond van die ressiltate van dir sriudie blyk dit dat die noeders an long

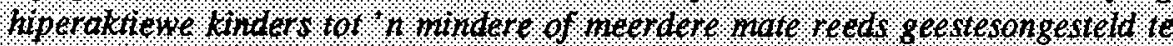

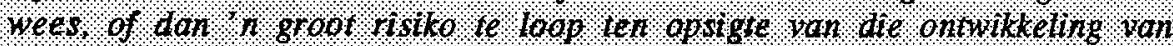

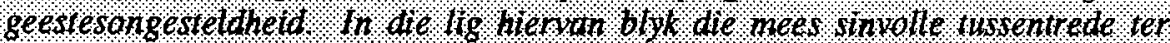

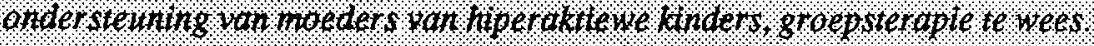

\section{SUMWTRT}

An exploratory contextudt study wos under token to expand the insight into and the

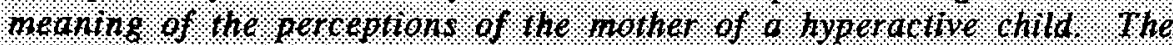

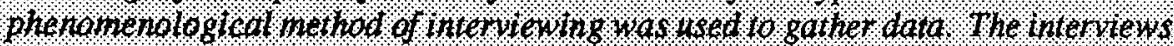
were recorded on tape and later transeribed verbatin The random test population condisted of eight porticipants who were specially selected for the purpose of this study. Data was onditysed by wayl of content andystis.

The results first ty cristatissed in the molther sesperientes with her hyperactive chita and secondly in the elentents which infuenced these experiences. The mother's experience is contained in her involvement with her child and in her ineraction with

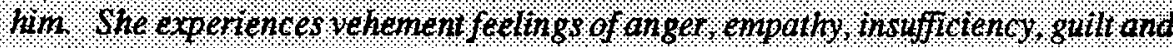
depression. At the same time there is the perception that she is responsible for her chitd's hyperactindy and the accomponying behaviourd probtems. The nother

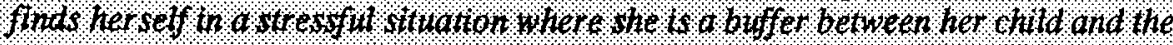

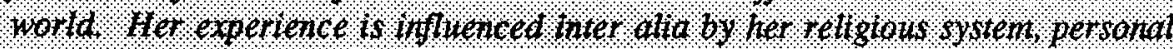
stress, the befiaviour of the hyperactive child, and the ovallobility of support systems

Based on the findings of ihis study, it seems that the nother of oung hyperactive

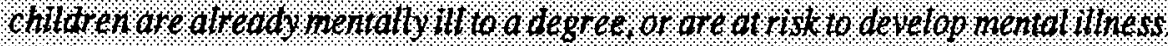

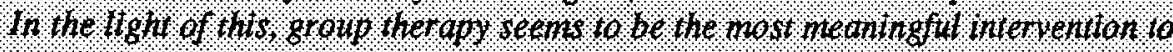
support mothers of young hyperactive children.

\section{INLEIDING}

Ouerskap bring ingrypende veranderings mee en word beskou as 'n kritieke oorgangsfase in die ontwikkeling van volwassenes (Cohier, 1984:119; Benedek, 1970:120). Dit is 'n langtermynproses wat baie verandering meebring en sekere aanpassings noodsaak (Van der Ede in Gerdes, et. al. 1981:185). Dit is dus ' $n$ besonder stresvolle ervaring vir ouers.

'n Belangrike bron van stres in die ouerskaprol, is die oortuiging dat aspekte van die moeder se sorggewende funksie, die belangrikste determinant van die kind se latere aanpassing is (Cohler, 1984:123). Sodoende word 'n groot verantwoordelikheid op die moeder geplaas.

Die stres wat inherent is aan die moederskaprol, neem geweldig toe wanneer 'n kind in die gesin geestesongesteld is (Gowen, Johnson-Martin, Goldman \& Appelbaum, 1989:259). Een so 'n geestesongesteldheid wat by kinders voorkom, is hiperaktiwiteit. Hiperaktiwiteit kan ernstige beperkings vir die kind se psigoso-siale ontwikkeling inhou, en dit het ook verreikende gevolge vir die gesin, en spesifiek die moeder van die hiperaktiewe kind (Barkley, 1981: Hoofstuk 2; Webster-Stratton \& Hammond, 1988:312). Moeders van hiperaktiewe kinders ondervind dikwels probleme in die hantering van hul kinders wat uiteindelik aanleiding gee tot gevoelens van onbevoegdheid, 'n gebrek aan selfvertroue in haar rol as moeder, asook depressie (Brown \& Pacini, 1989:584; Webster-Stratton \& Hammond, 1988:299; Breen \& Barkley, 1988:265; Mash \& Johnson, 1988:638).

Aangesien hiperaktiwiteit een van die mees algemene versteurings is wat in die kinderpsigiatriese verpleegpraktyk voorkom, en dit die moeder ten nouste raak, is dit belangrik om nie net die klem op die kind te laat val nie, maar ook ondersoek in te stel na die belewenis van die moeder van die hiperaktiewe kind.

\section{PROBLEEMSTELLING}

Uit persoonlike ervaring van die navorser blyk dit dat die moeders van hiperaktiewe kinders dikwels probleme ervaar bo en benewens die meer opsigtelike hanteringsprobleme. Dit wil 
voorkom asof hierdie moeders vir 'n geruime tyd op hul eie probeer om hierdie probleme te bowe te kom voordat professionele hulp gesoek word. Dit skyn ook makliker te wees om hulp te vra in terme van die hantering van die hiperaktiewe kind, as om met hul eie probleme na vore te kom.

In die praktyk waarin die navorser werksaam is, word die moeder van die hiperaktiewe kind ingesluit in die behandelingsprogram, maar behandeling is steeds primêr gefokus op die hantering van die kind. $\mathrm{Na}$ aanleiding van uitgebreide kontak met hierdie moeders het die vraag egter vir die navorser ontstaan of die moeders nie veel meer ervaar as waarvan die psigiatriese verpleegkundige bewus is nie. Sodanige vraag het grotendeels aanleiding gegee tot hierdie studie.

\section{DOELSTELLINGS VAN DIE STUDIE}

In die lig van waarneming wat tot die keuse van hierdie studie aanleiding gegee het, is die volgende ten doel gestel:

- Om die belewenis van die moeders van 'n hiperaktiewe kind te verken en te beskryf.

- Om riglyne daar te stel om moeders van hiperaktiewe kinders te ondersteun.

\section{PARADIGMATIESE PERSPEKTIEF VAN DIE STUDIE}

Metateoretiese aannames van die studie:

\section{Die kind.}

Die kind word gesien as 'n persoon wat nog nie volwassenheid bereik het nie; wat gesien word as ' $n$ waardige en unieke individu met die potensiaal om te groei.

Vir die doel van hierdie studie sal daar na die kind verwys word as hy of hom, maar dit is ook op sy of haar van toepassing.

\section{$\square$ Die gesin.}

Die gesin is ' $n$ basiese eenheid in ' $n$ gemeenskap wat nou verwant aan mekaar is. Die gesin lê die basis van die kind se sosialiseringsproses. Dit is ' $n$ dinamiese eenheid waarbinne wedersydse beinvloeding van al die lede plaasvind.

Vir die doel van hierdie studie sal moedertmoeders en haarthulle afwisselend gebruik word.

\section{Teoretiese aannames}

\section{TerminologielTeoretiese omskrywings}

i) Kinderpsigiatriese verpleegkundige.

'n Kinderpsigiatriese verpleegkundige is 'n professionele individu wat opgelei is om haarself op ' $n$ doelgerigte manier te gebruik om die hoogste moontlike vlak van gesondheid aan individue, families en gemeenskappe te fasiliteer (Poggenpoel, 1989:30).

Sy spesialiseer in kinderpsigiatriese verpleegkunde en is by die SA Raad op Verpleging geregistreer in na-basiese kinderpsigiatriese verpleegkunde (Steyn, 1987:32). Vir die doel van hierdie studie word na die psigiatriese verpleeg-kundige verwys as "sy" of "haar".

Na-basiese of nagraadse spesialisasie in kinderpsigiatriese verpleegkunde behels onder meer opleiding in:

- beraming van kinderpsigiatrieseversteurings

- spelterapie

- individuele terapie

- gesinsterapie

- aanbieding van ouerleidingskursusse.

ii) Hiperaktiwiteit.

Hiperaktiwiteit is 'n kliniese sindroom wat in die "Diagnostic and Statistical Manual of Mental Disorders" (DSM-III-R, American Psychiatric Association, 1987:56) opgeneem is as "Attention Deficit-Hyperactivity Disorder". In hierdie studie word verwys na hiperaktiwiteit as 'n sindroom wat veral gekenmerk word deur:

- 'n beperkte konsentrasievermoë;

- impulsiwiteit;

- oormatige motoriese aktiwiteitsvlakke; en

- nie-inskiklikheid (Befera \& Barkley, 1985:439).

\section{Metodologiese aannames}

Die wetenskaplike benadering wat in hierdie studie gevolg word, is funksioneel van aard daarin dat die navorsing wat uitgevoer word toepasbaar en bruikbaar in die veld van kinderpsigiatriese verpleegkunde is

\section{NAVORSINGSONTWERP EN -METODE}

\section{Navorsingsontwerp}

Hierdie studie is ' $n$ kwalitatiewe, verkennende studie met die doel om insig en betekenis uit te brei betreffende die belewenis van die moeder van 'n hiperaktiewe kind (Mouton \& Marais, 1989:43). Die fenomenologiese metode van onderhoudvoering is gebruik om data in te samel. Dit is 'n kontekstuele studie daarin dat die belewenis van 'n spesifieke teikengroep - moeders van hiperaktiewe kinders - verken word (Mouton \& Marais, 1989:49). In die beskrywende konteks word gepoog om ' $n$ sinvolle beskrywing van al die fasette van die belewenis van hierdie moeders te gee (Mouton \& Marais, 1989:44).

\section{Navorsingsmetode}

Die navorsingsmetode word kortliks uiteengesit met verwysing na betroubaarheid en geldigheid van die studie, steekproefneming, insameling van data verwerking van data, literatuuroorsig en daarstel van riglyne ter ondersteuning van moeders van hiper-aktiewe kinders.

\section{Betroubaarheid van die studie}

Woods \& Catanzaro (1988:136) wys op sekere faktore wat die betroubaarheid van kwalitatiewe studies kan beïnloed, insluitende:

- Die status of posisie van die navorser;

- Die sosiale konteks waarbinne die studie gedoen word.

- Die metodiek wat gevolg word.

Ten einde betroubaarheid te verseker, is die volgende kontrole-meganismes in hierdie studie ingesluit:

- Die rol van die navorser is duidelik geïdentifiseer;

- Die konteks (sosiaal, fisiek en interpersoonlik) waarbinne data ingesamel is, is duidelik uitgespel;

- Veldnotas is onmiddellik na die voltooiing van die onderhoud gemaak, ten einde te verseker dat dit akkuraat weergegee word

- Die strategieë wat gebruik word in die insameling, analise en beskrywing van data, is presies weergegee;

- Die bandopnames van die onderhoude is verbatim getranskribeer;

- Die kodering van die onderhoude is onafhanklik deur twee kodeerders gedoen

- Die bevindings is met gepubliseerde studies vergelyk (Woods \& Catanzaro 1988:136).

\section{Geldigheid van die studie}

Die geldigheid van 'n studie word onder meer beinvloed deur waarnemer effekte, en deur die wyse waarop deelnemers geselekteer word (Woods \& Catanzaro, 1988:137).

Daar is van die volgende strategieë gebruik gemaak om die geldigheid van hierdie studie te verseker.

- Onafhanklike bevestiging van verskeie deelnemers, dit wil sê onderhoude word met verskeie deelnemers gevoer;

- Die noukeurige analise van teenstrydige of uiteenlopende gevalle;

- Nougesette observasie; 
- Selfstandige en teoretiese kodering het versinsels aan die lig gebring;

- Deelnemers is streng volgens kriteria geselekteer (Woods \& Catanzaro, 1988:137).

\section{Steekproeftrekking}

- Steekproefpopulasie : Agt deelnemers is vir die studie geselekteer. Die deelnemers is volgens 'n gerieflikheids-, doelgerigte seleksie verkry (Abdellah \& Levine, 1979:333).

Bepaalde kriteria vir insluiting is gestel, naamlik

- 'n Moeder van 'n voorskoolse hiperaktiewe kind, wat oor die vermoë beskik om haar ervaring te artikuleer;

- Die diagnose van hiperaktiwiteit volgens die Diagnostic and Statistical Manual of Mental Disorders (DSM-III-R, American Psychiatric Association, 1987:56).

\section{Insameling van data}

Die fenomenologiese metode van onderhoudvoering is gebruik (Burns \& Grove, 1987:39\40). Die navorser het 'n ongestruktureerde onderhoud met deelnemers gevoer deur een oorkoepelende vraag te stel, "I would like you to share your thoughts, perceptions and feelings about your experience as the mother of this child as fully as possible."

Die onderhoude is op band opgeneem. Die navorser het onder meer van die volgende kommunikasietegnieke gebruik gemaak: ondersoek, parafrasering, reflektering van inhoud en gevoel, versoeke vir klarifikasie en vir voorbeelde en beskrywings, minimale respons en opklaring ten einde deelnemers aan te moedig om vrylik te kommunikeer.

Veldnotas is onmiddellik na elke onderhoud aangeteken om die hele onderhoudsituasie en die navorser se indrukke te beskryf.

\section{Analise van data}

Die bandopnames van die onderhoude is verbatim getranskribeer. Data is geanaliseer volgens Kerlinger (1986:477-483) se metode van inhoudsanalise. Die navorser het eers deur al die transkripsies gelees en die universele kategorieë van die data geïdentifiseer en gedefinieer. In die volgende stap van analise is eenhede van analise geïdentifiseer deur woorde en temas te onderstreep. Daarna is die woorde en temas geklassifiseer onder die geïdentifiseerde universele kategorieë. Die eenhede van analise is daarna in subkategoriee geklassifiseer. Die transkripsies van die onderhoude is aan ' $n$ psigiatriese verpleegspesialis gegee wat die data met behulp van 'n geskrewe werkswyse geanaliseer het. Die navorser en die psigiatriese verpleegspesialis het ontmoet en die resultate van hul analise vergelyk en tot 'n ooreenkoms gekom oor die kategorieë van eenhede van analise. Die kategoriee is daama geprioritiseer op grond van hoeveel deelnemers dieselfde aspek ervaar het.

Bespreking van resultate in vergelyking met toepaslike literatuur

Daarna is die resultate van die studie bespreek op grond van relevante literatuur en inligting bekom uit soortgelyke studies. Nuwe insigte bekom uit die navorsing is beklemtoon.

Opstel van riglyne vir die ondersteuning van moeders van hiperaktiewe kinders

Inligting bekom uit die studie en literatuuroorsig is gebruik om riglyne vir ondersteuning van moeders van hiperaktiewe kinders daar te stel.

\section{RESULTATE}

Vervolgens word 'n stapsgewyse uiteensetting van die resultate van die analise $v$ an die data gegee. Daarna volg 'n bespreking van die resultate van die studie, asook die interpretasie daarvan

\section{DEFINISIE EN KATEGORISERING VAN DIE UNIVERSUM}

Die universum in hierdie studie is al die verbale response van die deelnemers. As gevolg van die wyse waarop die vraag aan deelnemers gestel is, is die universum dus reeds tentatief as volg gekategoriseer:

\section{- Gedagtes:}

Gedagtes word gedefinieer as 'n idee, oordeel of mening wat die gevolg is van denke (Gouws, Louw, Meyer \& Plug, 1979: 94).

\section{- Persepsies:}

'n Persepsie is die psigiese produk van waarneming. Dit is dus die subjektiewe, bewuste belewenis van inligting wat uit die eksterne en interne omgewing ontvang en verwerk word. Vorige ondervinding speel 'n belangrike rol ten opsigte van persepsies (Gouws et al, 1979:228).

\section{- Gevoelens:}

Gevoelens is die bewuste belewenis wat deel vorm van 'n emosie, byvoorbeeld 'n gevoel van vreugde, woede en vrees (Gouws et al, 1979:105).

Met die verloop van die analise, en in konsultasie met 'n onafhanklike verpleegspesialis, is daar besluit om die volgende kategorieë as deel van die universum by te voeg:

\section{- Gedrag $H a n d e l i n g e:$}

Gedrag word beskou as willekeurige gedrag, waarby motivering 'n rol speel. Die gedrag is dus daarop gerig om 'n behoefte te bevredig of 'n doel te bereik (Gouws et al, 1979:95).

- Verhoudings:

Verhoudings word verder onderverdeel in die huweliksverhoudings, en ander sosiale verhoudings.

- Geloofstelsels:

'n Geloof word beskou as die aanvaarding van ' $n$ bewering \leerstelling sonder om die empiriese gronde daarvan te ondersoek (Gouws et al, 1979:98).

Dit het ook tydens analise geblyk dat daar nie veel verskil was tussen deelnemers se weergawes van hul gedagtes en persepsies nie. Daar is gevolglik besluit om genoemde kategorieë te kombineer in die bespreking; die kategorie gedagtes word geïnkorporeer by die bespreking van persepsies.

\section{BESPREKING VAN DIE RESULTATE}

Die resultate van hierdie studie kristalliseer eerstens uit in die moeder se ervaring met haar hiperaktiewe kind, en tweedens in die faktore wat hierdie ervaring affekteer.

Die ervaring van die moeder van die hiperaktiewe kind word vervat in haar betrokkenheid by haar kind, en in haar interaksie met hom. Verwys asseblief na Tabel 1 van hierdie bespreking.

Die moeder se betrokkenheid by haar hiperaktiewe kind behels haar bewustheid van hom as 'n kind wat op 'n onverklaarbare manier anders is. Dit omsluit haar persepsie dat hy van af geboorte 'n moeilike, veeleisende kind was wat konstant meer geëis het as waarin sy kon voorsien. Hieruit word 'n diep gevoel van skuld en ontoereikendheid gebore, en word die weg voorberei vir negatiewe interaksiepatrone waarin 'n toenemend ongelukkige moeder al hoe minder raad weet met haar onvergenoegde baba.

Die moeder se noue betrokkenheid by haar hiperak tiewe kind impliseer ook dat sy intense gevoelens jeens hom en ten opsigte van haarself ervaar. Sy nie-inskiklike-, ooraktiewe en impulsiewe gedrag maak haar by tye woedend, terwyl sy negatiewe reaksie op dissipline haar uiters gefrustreerd laat. Terselfdertyd ervaar sy byna grenslose empatie met haar kind en is daar groot begrip vir die feit dat hy hierdie gedragspatrone nie intensioneel en kwaadwillig openbaar nie. Hierdie oortuigings laat haar dan ook daadwerklik vir hom intree. Die moeder se diepgaande gevoelens vir haar kind laat haar terselfdertyd meer kwesbaar, sodat sy by tye desperaat en depressief voel.

Die nabyheid van hul verhouding maak hierdie moeders ook intens bewus van hul kinders se innemende en llefdevolle sy, en sy wens dat andere hom so kan sien. Sy besef dat hy meer positief reageer op geduld, liefde en koestering as op straf en ander dissiplinêre 
maatreëls. Dit laat haar egter in 'n onbenydenswaardige posisie omdat andere druk op haar plaas om haar kind te dissiplineer volgens metodes waarmee sy nie saamstem nie, of weet oneffektief is.

Die interaksie tussen moeder en kind word veral gekenmerk deur haar persepsie dat sy al die verantwoordelikheid ten opsigte van hom dra, en altyd daar moet wees vir haar kind. Sy impulsiwiteit en hiperaktiwiteit impliseer dat sy konstant toesig oor sy aktiwiteite moet hou en selde of ooit kan ontspan. Die moeders is baie bewus van die wederkerigheid van hul interaksie met hul kinders en aanvaar tot 'n groot mate verantwoordelikheid vir hul kinders se gedrag. Die interaksie tussen die deelnemers en hul kinders wentel dikwels rondom dissipline, en loop onvermydelik uit op verskille, woede-uitbarstings en 'n negatiewe siklus van interaksie. Die moeder probeer verskillende metodes van dissipline, met weinig sukses, en word gekonfronteer met toenemend uitdagende - en onaanvaarbare gedrag, sodat sy toenemend strafmaatreëls toepas, en selfs somtyds bekommerd is dat sy beheer sal verloor.

Die faktore wat die moeder se belewenis affekteer, is uiteenlopend en ineengeweef. Verwys asseblief na Tabel 2 van hierdie bespreking.

Sy self speel ' $n$ bepalende rol in terme van hoe sy hierdie ondervinding beleef. Fasette soos haar eie ervarings, haar geloofsisteem, haar evaluering van haarself, en persoonlike stres, dra by tot hierdie ervaring.

Haar eie kinderjare dra by tot haar verwagtings van haarself as moeder. Indien sy 'n ouer kind het met wie sy ' $n$ meer positiewe ervaring in terme van moederskap gehad het, voel sy meer paraat ten opsigte van die hantering van ' $n$ volgende kind, maar dit voorkom nie dat sy haarself as ontoereikend beleef en dieselfde skuldgevoelens ervaar as moeders van hiperaktiewe kinders wat nie 'n ouer kind het nie. Haar ondervinding met haar hiperaktiewe kind, waarin sy alle moontlikede ten opsigte van bantering eksploreer en probeer, lei tot 'n diepgaande gevoel van mislukking wat skynbaar moeilik omkeerbaar is.

Die moeders se basiese geloofstelse rol in hoe sy haar vertolking van die moederskaprol evalueer en beleef. Onrealistiese verwagtings, byvoorbeeld dat moederskap van nature kom, dra by tot haar gevoel van ontoereikendheid en mislukking. Die oortuiging dat ' $n$ mens se kinderjare sorgvry en gelukkig behoort te wees, en dat dit die moeder se plig is om dit te verseker, veroorsaak dat die deelnemers nie alleen voel dat hulle onsuksesvol is in die vertolking van hul primêre rol as sorggewer nie, maar ook hul kinders faal in die voorsiening van iets waarop elke kind geregtig is.

Die moeders se evaluering van hulself wissel grootliks. Daar is duidelike aanduidings van ambivalensie. Aan die een kant is daar die moeder se oortuiging dat sy nie ten volle verantwoordelikheid kan aanvaarvirhaar kind se gedragsprobleme en hiperaktiwiteit nie, dat sy inderdaad haar bes gedoen het, en dat daar ' $n$ inherente kwaliteit aan haar hiperaktiewe kind is wat bydra tot hul negatiewe interaksies. Daarteenoor is daar diepgesetelde skuldgevoelens, haar sin vir veantwoordelikheid, en die kritiek van andere wat daartoe lei dat sy haarself besonder negatief aanslaan, en meer blaam op haar neem as wat geregverdig blyk te wees.

'n Verdere bepalende faktor in hierdie moeders se belewenis van hul hiperaktiewe kind, is die ondervinding van stres. Haar noue emosionele betrokkenheid by haar kind vereis ontsaglike energie. Dit blyk dat die grootste hoeveelheid stres van die hiperaktiewe kind self afkomstig is. Onenigheid tussen sibbe dra verder hiertoe by, asook kritiek van andere. Die huweliksverhouding kan 'n betekenisvolle bron van ondersteuning wees, maar blyk in die meeste gevalle by te dra tot die moeders se hoë stresvlakke, veral op grond van ongemagtigde kritiek en 'n gebrek aan ondersteuning en hulp. Die moeders in hierdie studie bevind hulself dikwels in die onbenydenswaardige posisie waar hulle, reeds self onder die uiterste druk, optree as 'n buffer tussen 'n onmoontlike kind en 'n ongeduldige vader. Daardie behoeftes skyn die minste belangrik te wees en altyd ondergeskik aan dié van andere. Dit wil voorkom asof die deelnemers onvermydelik uitkom by 'n punt waar hulle voel dat hulle nie die stres kan hanteer nie.

Waarskynlik dié belangrikste aspek in die ervaring van die moeder van 'n hiperaktiewe kind, is die aard van sy gedrag. Hy is ooraktief, veeleisend, en impulsief. Hy is by tye aggressief en destruktief, en baie van sy gedrag blyk spesifiek op sy moeder gerig te wees. Hy stel homself in gevaar en daar moet sodoende konstant toesig oor hom gehou word. Daarbenewens veroorsaak hy onenigheid tussen sibbe, en dra by tot 'n atmosfeer van spanning en konflik net waar hy gaan. Hy blyk immuun te wees teen enige vorm van dissipline, en laat sy moeder met 'n gevoel dat sy nie kan deurdring tot hom nie. Hierdie gedragspatrone maak haar woedend sodat sy toenemende strafmaatreëls toepas, in desperaatheid van hom onttrek, en uiteindelik boedel oorgee.

Voorts speel die moeder se hanteringsmeganismes ' $n$ belangrike rol in haar ervaring met haar hiperaktiewe kind. Dit word tot 'n groot mate bepaal deur haar eie reserwes, maar ook deur die aan- of afwesigheid van ondersteuningstelsels. Die deelnemers aan hierdie studie se persoonlike reserwes het tot 'n groot mate geblyk uitgeput te wees. Haar hanteringsmeganismes is besig om te faal, en daarbenewens het hierdie moeders min ondersteuning van buite. Met die uitsondering van een deelnemer, beleef hierdie moeders hul huweliksverhoudings as onbevredigend in terme van die ondersteuning wat sy kry ten opsigte van hul hiperaktiewe kind. Dit is veel eerder ' $n$ bron van kritiek wat haar selfvertroue verder ondermyn. Hul sosiale omgewings blyk ook besonder stresvol te wees. Vriende se opmerkings met betrekking tot die hantering van die hiperaktiewe kind is gewoonlik krities en misplaas. Die moeder weet ook uit ondervindng dat sodanige vorms van dissipline nie effektief is nie, en onttrek liewer van sosiale bedrywighede as om voortdurend blootgestel te word aan kritiek.

Hierdie moeders het uiteraard nodig om hulself te beskerm. Dit blyk dat hulle aanvanklik neig om die probleem te ontken. Hulle stel hulself gerus dat hul kind deur 'n moeilike fase gaan en dit sal ontgroei. Dit word egter geleidelik duidelik dat hierdie probleem nie van verbygaande aard is nie, en inderdaad erger word. Ten spyte van haar pogings om dit te ontken, word hierdie gewaarwording dus al hoe sterker, en word die moeder gekonfronteer met 'n realiteit wat sy noodgedwonge moet erken.

Vir die meeste moeders gaan die erkenning van die probleem gepaard met aansienlike verligting. Dit impliseer dat dit 'n voldonge feit is en as sulks kan sy dan iets konstruktief daaraan begin doen. Dit is ook vir haar van waarde om te besef dat haar kind se hiperaktiwiteit en die gevolglike interaksionele probleme, nie eensydig is nie, en minder verantwoordelikheid daarvoor te aanvaar. Dit word dus vir haar makliker om hom te hanteer as sy hom sien as 'n kind met 'n bepaalde probleem, wat bydra tot hulle problematiese verhouding. Dit is verder gerusstellend vir hierdie moeders om te weet dat hulle inderdaad hulle bes probeer het.

Sommige van die deelnemers besef ook dat hulle nodig het om an ander aktiwiteite deel te neem en hulself met tye te distansieer van die intensiteit van hul interaksie met die hiperaktiewe kind en die meegaande stres. 'n Verdere wyse waarop hierdie moeders hulle situasie hanteer en hulself tot ' $n$ mate beskerm, is deur professionele hulp te soek.

Dit is duidelik dat die ervaring van die moeder van die hiper- aktiewe kind vele fasette het, en 'n ongekende intense, en dikwels hartseer, ondervinding is.

\section{NUWE INSIGTE BEKOM UIT HIERDIE STUDIE}

Vervolgens word die nuwe insigte wat uit hierdie studie na vore gekom het, bespreek. Diskrepansies tussen bevindings van hierdie studie en bestaande navorsingsresultate sal ook uitgelig word.

Campbell (1990:19) maak melding daarvan dat ' $n$ veeleisende baba gevoelens van woede in die moeder ontketen. Die intensiteit van die woede wat die moeders ervaar, kom egter baie duidelik na vore in hierdie studie, en bereik kommerwekkende afmetings daarin dat 
moeders gereeld van fisieke straf gebruik maak en by tye vrees dat dit oormatig is.

Hierdie studie vul 'n leemte met betrekking tot die navorsing wat gedoen is ten opsigte van jonger hiperaktiewe kinders. Alhoewel hierdie nie ' $n$ vergelykende studie is nie, is dit duidelik dat moeders van hiperaktiewe jong kinders reeds intense gevoelens van ontoereikendheid en skuld ervaar. Depressie kom ook by die meerderheid deelnemers voor.

Geen studies tot die navorser se beskikking maak melding van die positiewe aspekte van die verhouding tussen moeders en hul hiperaktiewe kinders nie. Die bevindings van hierdie navorsing dui daarop dat hierdie moeders se diep gevoelens van empatie met hul kinders aangrypend is. Hulle is opreg besorg oor verskeie fasette van hul kinders se gedrag en die implikasies wat dit vir hulle inhou. Die deelnemers is bekommerd oor hul kinders se onvermoë om vriende te maak, en word diep getref deur hul kinders se afgesonderdheid. Die toekoms hou ook baie twyfel in - die moontlikheid dat hul kinders akademies probleme sal ondervind of ' $n$ gedragsafwyking sal ontwikkel, wek groot kommer.

Daar is 'n pynlike bewustheid van die hiperaktiewe kind se innemende en liefdevolle sy, en 'n begeerte dat andere hom so kan sien. Sy beskryf met groot deernis hoe haar kind soms werklik probeer om sy gedrag te kontroleer, met min sukses. Ten spyte van sy onmoontlike gedrag, is daar ook by hierdie moeders 'n seker wete dat sy gedrag buite sy beheer is en dat dit nie kwaadwillig is nie. Hierdie gevoelens laat terselfdertyd haar eie kwesbaarheid toeneem.

Aansluitend by verskeie studies met betrekking tot die huweliksverhouding, ervaar die deelnemers aan hierdie studie dat die onmin en konflik in die huweliksverhouding toeneem, en dat dit nie werklik ' $n$ bron van ondersteuning is nie. Daarbenewens bevind die moeder haar in die onbenydenswaardige posisie waar sy 'n buffer is tussen haar huweliksmaat en hul hiperaktiewe kind, wat verder bydra tot haar hö̈ stresvlakke. Die moeder is deurentyd bewus daarvan dat haar man beskerm moet word teen die spanning wat 'n hiperaktiewe kind noodwendig in die huis veroorsaak. Terselfdertyd tree sy in vir haar kind wanneer dit voorkom asof haar man ongeduldig of te bestraffend is. Haar eie behoeftes blyk deurgaans op die agtergrond te wees. In teenstelling met haar mededelings dat sy dit nie langer kan hanteer nie, handhaaf die deelnemers ' $n$ fasade en gee voor dat hulle in beheer is van die situasie.

'n Persepsie wat baie sterk na vore gekom het is dat die deelnemers oortuig is dat hulle deels verantwoordelik is vir hul kind se hiperaktiwiteit en gedragsprobleme. Dit is meer as 'n gevoel van ontoereikendheid, of 'n onvermoë om die kind se gedrag te hanteer, veel eerder 'n wesenlike aandadigheid. Sy bevraagteken haarself gedurig ten opsigte van haar optredes enbf versuime wat 'n rol kon speel in die ontstaan en voortsetting van die hiperaktiwiteit. Hierdie presensie gee aanleiding tot oneindige skuldgevoelens en 'n gevoel dat sy haar kind gefaal het.

In die studies tot die navorser se beskikking word melding gemaak van die toenemend dissiplinêre maatreëls waarvan ouers gebruik maak in 'n poging om hul kind se gedrag te beheer. In die huidige studie blyk dit dat moeder wel hiervan gebruik maak, ten spyte daarvan dat sy weet dit is oneffektief. Sy is egter oortuig daarvan dat hy respondeer op liefde en ' $n$ positiewe benadering, eerder as strafmaatreëls, en dat fisieke straf minder effektief is.

Die deelnemers van hierdie studie se geloofsisteme speel voorts 'n belangrike rol in haar perspesie ten opsigte van haar rol as moeder. Die oortuiging dat 'n kind se vroeë kinderjare sorgvry en gelukkig behoort te wees, en dat dit die moeder se plig is om dit te verseker, dra verder by tot haar skuldgevoelens. Sy glo ook dat, van alle mense, 'n moeder dié een is wat tot haar kind moet kan deurdring.

\section{GEVOLGTREKKINGS}

Vanuit die resultate blyk dit dat die moeder 'n sentrale figuur is wat as buffer tussen die hiperaktiewe kind en sy omgewing dien. Vervolgens word gevolgtrekkings gemaak aan die hand van Figuur 1.

Die moeders in hierdie studie blyk vasgevang te wees in 'n moeilike posisie. Hulle ervaar intense gevoelens jeens hulle hiperaktiewe kinders, maar ook ten opsigte van hulle self. Haar kind se hiperaktiewe gedrag en negatiewe respons op haar pogings om hom te dissiplineer, laat haar woedend en magteloos. Sy ervaar egter terselfdertyd empatie met haar kind en word diep geraak deur sy hartseer. Daar is ' $n$ aangrypende bewustheid van sy innemende en liefdevolle sy. Daar is bekommernis oor die toekoms en die implikasies wat sy gedrag vir hom inhou. Sy het ook begrip vir die feit dat hy nie altyd beheer het oor sy gedrag nie, en dat dit nie kwaadwillig is nie.

Daarteenoor laat die aard van die hiperaktiewe kind se gedrag, die konstante spanning in die huis en die onenigheid tussen sibbe, haar in 'n posisie waar sy voel dat sy die situasie nie verder kan hanteer nie. Sy glo ook dat sy haar kind op 'n manier moet kan hanteer, en maak sodoende gebruik van toenemende strafmaatreëls, wat dan bydra tot haar skuldgevoelens. Haar observasie dat weinig van haar pogings om deur te dring tot haarkind suksesvol is, gee aanleiding tot gevoelens van ontoereikendheid en depressie.

Hierdie moeders is ambivalent ten opsigte van verskeie aspekte van hul ervaring met hul hiperaktiewe kinders. Aan die een kant is daar die persepsie dat sy aandadig is aan haar kind se hiperaktiwiteit en meegaande probleme.
Daarteenoor is daar ' $n$ oortuiging dat daar ' $n$ inherente kwaliteit aan die kind is waarvoor sy nie verantwoordelikheid kan aanvaar nie. Hierdie konflikterende gedagtes word egter nooit werklik bygelê nie, en speel ' $n$ belangrike rol in die voortsetting van die skuldgevoelens wat sy ervaar.

Ter opsomming blyk dit dat hierdie moeders hulself inderdaad in ' $n$ onbenydenswaardige posisie bevind. Sy ervaar intense en konflikterende gevoelens, wat op sigself baie energie vereis, en besonder stresvol is. Sy aanvaar verantwoordelikheid, beide in terme van aandadigheid ten opsigte van haar kind se hiperaktiwiteit, en in terme van daadwerklike pogings om deur te dring tot haar kind en oplossings te soek vir hul uiters moeilike omstandighede.

Daarbenewens raak haar ervaring met haar hiperaktiewe kind haar ten diepste - dit dring deur tot die kern van haar verwagtings van haarself as moeder, een van die belangrikste rolle wat sy ooit sal vervul. Daar blyk baie min te wees om hierdie diep twyfel in haarself, hierdie faling in haar rol as primêre sorg-gewer, te besweer. Haar eie ambivalensie dra hiertoe by, maar kritiek van andere en in die besonder haar huweliksmaat, bevestig voortdurend haar aandadigheid en haar rol in die voortsetting van die probleme.

Sy bevind haarself voortdurend in die middel van die konflik - in die voorste linie van verdediging. Sy is die buffer tussen haar hiperaktiewe kind en die wêreld daarbuite. Die moeder tree tussenbeide wanneer hul hiperaktiewe kind se gedrag onhanteerbaar is vir haar man wat reeds aan ' $n$ stresvolle beroep blootgestel is, en geregtig is om 'n vreedsame en rustige omgewing. Haar empatie en begrip laat hierdie moeder baie beskermend teenoor haar kind voel, en sy kom dikwels tot sy verdediging wanneer sy dink dat haar man onregverdig is teenoor hom, of wanneer hy deur sy portuurgroep verwerp word. Terselfdertyd is sy bewus daarvan dat hy sal moet leer om vriende te maak en onafhanklik van haar die mas op te kom.

Die onenigheid tussen die hiperaktiewe kind en sy sibbe is 'n verdere area waar die moeder blyk vasgevang te wees in 'n dilemma. Sy het begrip vir haar hiperaktiewe kins se gedrag, maar is terselfdertyd bewus van haar ander kindkinders se regte om beskerm te word en in 'n gelukkige huis met sekuriteit groot te word.

Sy tree dus daadwerklik in vir haar kind in 'n wêreld wat grootliks onbegrypend en vyandig is. Wat meer is, is dat hierdie moeders dit doen met die minimum ondersteuning en hulp. Sy is voortdurend blootgestel aan uitermatige stres, en word dikwels gekritiseer. Haar eie behoeftes blyk altyd op die agtergrond te wees, en hoegenaamd nie 'n prioriteit nie. Dit wil dus werklik voorkom asof hierdie moeders 'n bykans ondraaglike lading grootliks op hul eie dra. 


\section{TEKORTKOMINGE}

Die volgende is as tekortkominge in hierdie studie geidentifiseer:

Die aantal deelnemers is ' $n$ beperkende faktor. Alhoewel hierdie studie nie bedoel was om veralgemeenbaar te wees nie, sou die insluiting van 'n groter aantal deelnemers die studie kon verdiep en insigte verbreed.

Die wyse waarop die instruksies aan deelnemers gestel is, naamlik: "I would like you to share your thoughts, perceptions and feelings about your experience as the mother of this child as fully as possible", het die universum reeds tentatief gekate-goriseer in gedagtes, perspesies en gevoelens. Hoewel sekere outeurs wel van 'n rigtende vraag gebruik maak, sou dit waar- skynlik vir die doel van hierdie studie meer sinvol gewees het om nie 'n rigtende vraag te stel nie.

\section{AANBEVELINGS}

Vervolgens sal aanbevelings gemaak word deur eerstens te verwys na die toepassingsmoontlikhede van hierdie studie in terme van onderrig, praktyk en navorsing, en tweedens riglyne te stel ter ondersteuning van moeders van jong hiperaktiewe kinders.

\section{TOEPASSINGSMOONTLIKHEDE}

Hoewel hierdie studie in sekere opsigte beperk is, is daar vele toepassingsmoontlikhede vir die toekoms. Die resultate van hierdie studie behoort ingesluit te word in die kurrikulum vir kinderpsigiatriese verpleegkunde, beide op nagraadse en na- basiese vlak. Die bevindings kan ook op 'n meer informele basis gedeel word met lede van die multi-dissiplinêre span werksaam in Kinder- en Gesinseenhede en Kinderleidingklinieke.

Ten opsigte van die praktyk, het hierdie studie implikasies vir die behandeling van die hiperaktiewe kind en sy moeder. Dit sal meer breedvoerig bespreek word onder die spesifieke riglyne.

Die toepassingsmoontlikhede in terme van navorsing is onbeperk. Tot dusver weerspieël die literatuur hoofsaaklik beskrywings van hiperaktiwiteit as geestesongesteldheid. Verdere ondersoek kan ingestel word om ook diekind se eie belewenis van sy hiperaktiwiteit te beskryf. 'n Vraag wat ontstaan uit die resultate van hierdie navorsing, is hoe hierdie moeders 'n bykans onmoontlike taak verrig, veral in die lig van haar beperkte ondersteuningstelsels en die geweldige stres waaronder sy verkeer. Die rol wat 'n spesifieke ondersteuningstelsel byvoorbeeld godsdiens in terme van die moeder se hantering van haar kind speel, kan verder ondersoek word. So ook kan daar gekyk word na die moontlikheid dat die ouers se huweliksprobleme bydra tot die negatiewe interaksie tussen moeder en kind, deurdat die moeder haar probleme projekteer. 'n Baie pertinente vraag ontstaan in terme van hiedie moeders se altruïsme, daarin dat haar optrede so self-opofferend is, sonder dat sy dit bevraagteken, en kan interessante navorsingsmateriaal wees.

\section{RIGLYNE TER ONDERSTEUNING VAN DIE MOEDER VAN DIE HIPERAKTIEWE KIND}

Die bevindinge van hierdie studie word opgesom in Figuur 1 en dit word vervolgens as vertrekpunt gebruik vir die daarstelling van riglyne ter ondersteuning van die moeder van die jong hiperaktiewe kind.

Dit blyk duidelik uit hierdie visuele voorstelling dat die onbenydenswaardige posisie waarin die moeder van ' $n$ hiperaktiewe kind haar bevind, as buffer tussen haar kind en die wêreld, met min ondersteuning en beperkte ondersteuningstelsels, sekere implikasies het met betrekking tot haar geestesgesondheid. Die resultate van hierdie studie dui daarop dat die deelnemers by tye depressief is en voel dat hulle reserwes uitgeput is. Daar is dus duidelike aanduidings dat ' $n$ risiko bestaan vir die ontwikkeling van geestesongesteldheid of dat geestesongesteldheid reeds teenwoordig is. Uit die voorafgaande bespreking blyk dit duidelik dat hiperaktiwiteit by 'n kind, en die moeder se ouerskapsvaardighede nou ineenskakel en tot 'n groot mate verweef is. Die ervaring van die moeder wat daarop dui dat sy geleidelik minder vertroue in haar bedrewenheid as ouer het, tesame met die toename in die kind se problematiek, is duidelike aanwysers vir vroeë tussentrede.

As gevolg van die konsekwente ouderdomsverwante verskille in moeders se ervaring van stres en 'n afname in selfagting ten opsigte van ouerskapsvaardighede, beveel Mash \& Johnston (1988:648) aan dat die tipe tussentrede aangepas word na gelang van die spesifieke behoeftes in die gesin. Daar word ook klem gelê op die belang van vroeë ingryping.

Op grond van die resultate van hierdie studie blyk die deelnemers tot ' $n$ meerdere of mindere mate reeds geestesongesteld te wees, of dan 'n groot risiko te loop ten opsigte van die ontwikkeling van geestesongesteldheid. In die lig hiervan blyk die mees sinvolle tussentrede ter ondersteuning van die moeders van hiperaktiewe kinders, groepsterapie te wees. Die voordele van groepsterapie bo ander metodes van tussentrede, is opgesluit in dievolgende terapeutiese faktore, aan die hand waarvan riglyne gestel word ter ondersteuning van moeders van jong hiperaktiewe kinders (Yalom, 1985:Hoofstuk 4):

- Die daarstel van hoop: die deelnemers aan hierdie studie se reserwes is uitgeput, en hul hanteringsmeganismes besig om te faal. Daarstelling van hoop kan dus grootliks bydra om hul hanteringsmeganismes in stand te hou.

- Universaliteit: 'n gemeenskaplike denominator bestaan daarin dat almal moeders van 'n hiperaktiewe kind is, en sodoende 'n unieke ervaring deel. In groepsterapie kry groepslede 'n persepsie van hul ooreenkomste met andere, en kan dus hul diepste besorgdhede deel. Hulle baat by die gepaardgaande katarsis en die aanvaarding deur die groepslede, veral in die lig van hul ervarings in hul eie sosiale omgewing, waar hulle dikwels gekritiseer word, en waarvan hulle geleidelik onttrek het.

- Deel van inligting: hierby ingesluit is didaktiese instruksies, asook raad, voorstelle en leiding. Alhoewel die proses eerder as die inhoud voordelig is daarin dat dit belangstelling en empatie impliseer en oordra, kan die deel van inligting 'n belangrike faset wees vir hierdie moeders. Deurdat hulle meer inligting verkry rakende hiperaktiwiteit as sulks, kan hulle skuldgevoelens ten opsigte van hul eie rol in die veroorsaking daarvan aangespreek word. Voorts kan belangrike aspekte soos dissipline en streshantering aandag geniet.

- Altruïsme: groepslede ontvang as't ware deur te gee - nie alleen deur die wederkerige gee-ontvang volgorde nie, maar ook deur die intrinsieke "act of giving." Altruïsme blyk 'n integrale deel van hierdie moeders se lewens te wees, daarin dat hulle tot die uiterste selfopofferend is in hul funksie as buffer tussen hul kinders en die wêreld. Dit kan dus met groot vrug aangewend word in 'n groepsterapie situasie. Groepslede help mekaar deur ondersteuning, gerusstelling, voorstelle en insig en deur probleme met mekaar te deel.

- Groepskohesie: groepskohesie is 'n primêr bydraende faktor tot die terapeutiese ondervnding. Dit dra onder andere by tot toenemende vlakke van selfopenbaring en meer deelname deur groepslede. Die moeders ervaar hierdeur ook gemeen- skaplikheid wat as ondersteuningsfaktor dien.

- Katarsis: katarsis is deel van 'n interaksionele proses en kan van groot waarde wees vir hierdie moeders wat so 'n geweldige lading op hul eie dra. Die resultate van hierdie studie het onteenseglik daarop gedui dat die deelnemers intense en by tye ambivalente gevoelens ervaar.

- Eksistensiële faktore: hierdie faktore kan 'n bepalende rol speel in die groepslede se ervaring van die groepsterapie. Dit is veral belangrik vir hierdie moeders wat worstel met vrae soos hoe anders hul lewens dalk sou verloop sonder hul hiperaktiewe kinders. Aansluiting kan dus in die eksistensiële benadering gevind word, waar-volgens "...the human being's paramount struggle is with the givens, the ultimate concerns, of existence: death, isolation, freedom and meaninglessness...." (Yalom, 1985: 95). 
Dit blyk dus dat groepsterapie effektief aangewend kan word as ' $n$ terapeutiese tussentrede vir die moeders $v$ an jong hiperaktiewe kinders.

\section{SLOTSOM}

Dit is duidelik dat die ervaring van die moeder van die hiperaktiewe kind vele fasette het, en 'n ongekende intense, en dikwels hartseer, ondervinding is. Terapeutiese tussentrede is dus sonder enige twyfel aangewese, aangesien beide moeder en kind in 'n hoë risiko is met betrekking tot die ontwikkeling entof verergering van geestesongesteldheid. Dit is egter belangrik dat die probleem in totaliteit aangespreek word, veral in die lig daarvan dat probleme ten opsigte van eksternaliserende gedrag by jong kinders geneig is om te bly voortbestaan indien dit geassosieer word met gesinsdisfunksie en 'n negatiewe moeder-kind verhouding (Campbell, Breaux, Ewing \& Szumowski, 1986:232).

\section{BIBLIOGRAFIE}

ABDELLAH, FG \& LEVINE, E 1979 : Better patient care through nursing research. Second edition. New York : Macmillan Publishing Company.

\section{AMERICAN PSYCHIATRIC} ASSOCIATION 1987 : Diagnostic \& Statis- tical Manual of Mental Disorders. Washington, DC :3rd Ed, revised.

BARKLEY, RA 1981 : Hyperactive Children : A Handbook of Diagno- sis \& Treatment. New York : The Guildford Press.

BEFERA, MS \& MARKLEY, RA 1985 : Hyperactive \& Normal Girls \& Boys: Mother-child interaction, parent psychiatric status \& child psychopathology. Journal of Child Psychology \& Psychiatry. 26(3), 1985:439 $-451$.

BENEDEK, T 1970 : The Family as a Psychologic Field. In EJ Anthony \& $\mathrm{T}$ Benedek (Eds) Parenthood: Its psychology \& psychopathology. Boston: Little Brown \& Co.

BREEN, MJ \& BARKLEY, RA 1988: Child Psychopathology and Parenting Stress in Girls \& Boys having Attention Deficit Disorder with Hyperactivity. Journal of Paediatric Psychology. 13(2), 1988:265 280.
BROWN, RT \& PACINI, JN 1989 : Perceived Family Functioning, marital status and depression in parents of boys with attention deficit disorder. Journal of Learning Disabilities. 22(9), 1989:581 - 587.

BURNS, N \& GROVE, SK 1987 : The practice of nursing research conduct, critique and utilization. Philadelphia : W.B. Saunders.

CAMPBELL, SB 1990 : Behaviour Problems in Preschool Children. Clinical and Developmental Issues. New York : The Guilford Press.

CAMPBELL, SB., BREAUX, A., EWING, LJ \& SZUMOWSKI, EK 1984 : A One-year Follow-up Study of Parent-referred Hyperactive Preschool Children. Journal of the American Academy of Child \& Adolescent Psychiatry. 23(3), 1984: 243 - 249.

CILLIERS, AJ 1991 : Ondersteuningsriglyne aan moeders met jong hiperaktiewe kinders. Johannesburg : Randse Afrikaanse Universiteit. Ongepubliseerde M. Cur.-skripsie.

COHLER, BJ 1984 : Parenthood, psychopathology and child care. In RS Cohen, BJ Cohler \& SH Weissman (Eds) Parenthood: A Psychodynamic Perspective. New York: The Guilford Press.

GERDES, LC., OCHSE, R., STANDER, CR \& VAN DER EDE, D 1981 : Die ontwikkelende volwassene. Durban : Butterworth.

GOUWS, LA., LOUW, DA., MEYER, WF \& PLUG, C 1979 : Psigologie- woordeboek. Johannesburg : McGraw-Hill.

GOWEN, JW, JOHNSON-MARTIN, N., GOLDMAN, BD \& APPELBAUM, M 1989: Feelings of depression and parenting competence of mothers of handicapped and nonhandicapped infants : a longitudinal study. American Journal on Mental Retardation.94(3).

KERLINGER, FN 1986 : Foundations of Behavioral Research. New York: Rinehart and Winston Inc.

MASH, EJ \& JOHNSTON, C 1988 : Parental Perceptions on Child Behavior Problems, Parenting Self-Esteem and Mothers' reported Stress in Younger and Older
Hyperactive \& Normal Children. In EM Hetherington \& RD Parke (Eds) Contemporary Readings in Child Psychology 3rd Ed. New York : McGraw-Hill.

MOUTON, J \& MARAIS, HC 1988 : Metodologie van die geestesweten-skappe : Basiese begrippe. Pretoria : Raad vir Geestes- wetenskaplike Navorsing.

POGGENPOEL, M 1989 : Psychiatric Nursing Conceptual Model. Johannesburg : Randse Afrikaanse Universiteit (unpublished final research report).

STEYN, E 1987 : Die bydrae van die kinderpsigiatriese verpleeg- kundige tot primêre geestesgesondheid. Johannesburg : Randse Afrikaanse Universiteit (M. Cur.-proefskrif)

WEBSTER-STRATTON, C \& HAMMOND, M 1988 : Maternal depression and its relationship to life stress, perceptions of child behavior problems, parenting behaviors and child conduct problems. Journal of Abnormal Child Psychology. $16(3) 299-315$

WOODS, NF \& CATANZARO, M 1988 : Nursing Research, theory and practice. St. Louis : The CV Mosby Company.

YALOM, ID 1985 : The theory and practice of group psychotherapy. New York : Basic Books Inc.

Alida Joan Cilliers

$G A V ., G V V ., G P V$.

M.Cur. (Psigiatriese

Verpleegkunde-Kinderpsigiatrie)-Student

Hoofverpleegkundige, Transvaal Memorial Institute for Child Health and Development.

Minrie Greeff

GAV., GVV., Gevorderde GGV., PV., DVO en DVA.

D.Cur. (Psigiatriese Verpleegkunde)

Lektrise, Departement Verpleegkunde Randse Afrikaanse Universiteit.

Marie Poggenpoel GAV., GVV., GGV., GPV, DVO en DVA D. Phil (Verpleegkunde-Psigiatries.)

Professor, Departement Verpleegkunde, Randse Afrikaanse Universiteit. 